\section{Everyman's Mathematics}

By F. G. Brown. Pp. xix +748 . (Sydney and London: Angus and Robertson, Ltd., 1947.) $36 s$.

A FTER fifty years of teaching in primary and A secondary schools, teachers' training colleges, adult classes, and the Royal Australian Naval College, Mr. Brown is very much dissatisfied with the usual methods of teaching elementary mathematics. $\mathrm{He}$ considers that the few basic principles are clouded and hidden by an over-elaboration of the details, and that much time is wasted in doing too much in the wrong way. He has therefore prepared a treatment which, though mainly an attempt to interest the adult who has forgotten what he learned at school, also suggests, in the first half of the book, the minimum amount of mathematics which a school might be expected to teach to boys and girls of fifteen years of age. This part deals with arithmetic (based almost entirely on the "method of Rates"), geometry, algebra and trigonometry. The second half of the book illustrates the type of material suitable for use in an adult education study-group ; it lays stress on applications to instalment systems, depreciation, decibels and phons, dynamic design, fallacies and puzzles, as well as on more conventional branches of mathematics such as graphs and calculus.

Both parts of the book are written in amusing and colloquial language, with anecdotes, historical references, and digressions, some of which throw more light on the author's opinions on things in general than on mathematics. There are many examples for solution, and the answers are given at the end of the book, in some cases with hints how to obtain them. There is a full index.

Any portion of the book, taken by itself, is very readable; but taken altogether, there is too much of everything. The publishers' claim that the book is for every man and woman raises two questions. Is every man prepared to read such a large book (more than 750 pages), and if so, is he prepared to pay $36 s$. for it?

H. T. H. Piaggio

\section{Plasticity in Engineering}

By F. K. Th. van Iterson. Pp. ix +174 . (London, Glasgow and Bombay: Blackie and Son, Ltd., 1947.) 8s. 6 d. net.

$\triangle \mathrm{S}$ the author rightly claims in the preface, the A chief reason for writing a book on the theory of plasticity is to direct attention to its importancefrom the engineering point of view equal to that of the theory of elasticity. Nevertheless, to be of real value, such a book must review the state of knowledge of the subject as a whole, or, on a smaller scale, provide an introduction to the subject, dealing only with well-established theoretical and experimental results.

This book fulfils neither function adequately, and is correspondingly of limited value to the research worker and of real danger to the student. The author has instead developed in it a group of theoretical results, which are neither based on an adequate consideration of the theoretical background, nor supported by convincing experimental evidence; in this connexion, the author has had access to a considerable field of Dutch work, but unfortunately gives only very abbreviated accounts of it. American work, other than the edition in English of Nadai's famous book, is covered in four brief references, and it is unfortunate that the author has apparently not been aware of the important work being done in Great Britain. In the past eighteen months, for example, a collection of papers has been published by R. Hill and fellow-workers, which involve conclusions very different from many of those described.

The valuable features are a considerable collection of recent references, scattered through the book, to Continental work, some illuminating introductory chapters on fundamental aspects of the subject, and a few interesting photographs and diagrams relating to observed results.

G. D. S. MacLellan

\section{Flowering Earth}

By Donald Culross Peattie. Pp. vii +200. (London : Phœnix House, Ltd., 1948.) 10s. 6d. net.

$T$ HIIS book is an unusual introduction to the study and appreciation of plant life. The theme running through it is the unity-more particularly in a symbiotic sense of all living organisms. It is very clearly shown that plants with chlorophyll are basic to the existence of all living organisms, except a few "bacterial autotrophs". Hence, "we ought not to speak of getting at the root of a matter, but of going back to the leaf of things". The main groups and functions of plants are considered in extremely simple language and with the use of a minimum of technical terms.

The opinion may be expressed that a majority of the persons to whom this book might appeal would prefer a little more 'meat' in the eighteen chapters. On the whole, the statements concerning plants are accurate and up to date; but some corrections are necessary. The number of species of flowering plants is stated on p. 124 to be "some one hundred thousand", while on p. 152 "two hundred thousand species" of Angiosperms are said to "populate our flowering world". Kerguelen was certainly visited by Sir Joseph Hooker, but this island is usually con. sidered as being in the southern part of the Indian Ocean and not in the Pacific. It is unfortunate that the desire for simplification of language has led to the use of such phrases as "tiny acids" and to the manufacture of such a plural as "algas". The author is obviously a sincere lover of plants and many of his philosophical ideas are admirably expressed.

\section{W. B. TURRILL}

\section{Royal Society Empire Scientific Conference, June- July 1946}

Report. Vol. 1. Pp. 828. Vol. 2. Pp. 707. (London : Royal Society, 1948.) 2 vols., $42 s$. net.

THE Report of the Royal Society Empire Scientific Conference, June-July 1946, now issued in two handsome volumes, includes the speeches at the opening ceremony, the papers presented, and recommendations and notes on the discussions (see also Nature, July 27, 1946, p. 136). In addition to the "Notes on Current Scientific Researches in the United Kingdom" prepared by the Royal Society, various papers on the organisation of scientific research in the Colonies, in Canada, India, New Zealand, South Africa and Southern Rhodesia give a very useful conspectus of the organisation of such research throughout the British Commonwealth of Nations. The volumes are admirably indexed, and the immense amount of information they contain is made accessible to the reader in a way worthy of the Royal Society and setting a standard that might well be followed widely. They constitute both a worthy record and a reference work on scientific research, information services and related topics in the Empire that should be valuable for several years to come. R. B. 